\title{
TVA, Abnormal Return, and Investor Perception on Changing of Tick Size 2 May 2016
}

\author{
Astri Wening Perwitasari, Tri Gunarsih \\ Department of Management, Faculty of Economics and Business, University of Technology Yogyakarta \\ Jl. Ringroad Utara, Jombor, Sleman, 55285, Indonesia
}

\begin{abstract}
Keywords: Abnormal Return; Investors Perception; Tick size; Trading Volume Activity

JEL Classification: G11, G12, G23

Kata Kunci: Abnormal Return; Persepsi Investor; Fraksi Harga; Aktivitas Volume Perdagangan

The objective of this study was to analyze the market reaction to the changing of capital market's tick size regulation in May $2^{\text {nd }}, 2016$. The main goal of the regulation was to increase the capital market liquidity, then it's important to test whether there was a difference in market liquidity before and after the regulation released. The method of this study was studying with Trading Volume Activity (TVA) and abnormal return based on secondary data and also investor perception based on primary data. The secondary data consist of 65 samples of listed companies in Indonesia Stock Exchange. The primary data consist of 67 investors in Yogyakarta that were selected using purposive sampling method. The result of this study was mix, there was no difference before and after the release of regulation in TVA, but there was a difference in abnormal return. The result of investor perception shows that there was a positive response to the changing of tick size regulation.

ABSTRAK

Penelitian ini bertujuan untuk menganalisis reaksi pasar terhadap perubahan peraturan fraksi harga saham pada tanggal 2 Mei 2016. Tujuan utama peraturan ini adalah untuk meningkatkan likuiditas pasar modal, sehingga penting untuk menguji apakah ada perbedaan likuiditas pasar sebelum dan sesudah adanya perubahan peraturan tersebut. Metode penelitian ini adalah studi peristiwa dengan menggunakanTrading Volume Activitity (TVA) dan abnormal return pada data sekunder dan persepsi investor berdasarkan data primer. Data sekunder terdiri dari 65 sampel perusahaan terbuka di Bursa Efek Indonesia. Data primer terdiri dari 67 investor di Yogyakarta yang dipilih menggunakan metode purposive sampling. Hasil penelitian menunjukkan bahwa tidak ada perbedaan TVA sebelum dan sesudah adanya perubahan peraturan fraksi harga, namun demikian abnormal return menunjukkan adanya perbedaan sebelum dan sesudah. Hasil penelitian pada persepsi investor, menunjukkan bahwa terdapat respon positif terhadap perubahan peraturan fraksi harga.
\end{abstract}


The capital market connects between investors and those in need of funds (issuers). The Indonesia Stock Exchange (IDX), the institution or organization that organizes the capital market in Indonesia, always strives to increase investment for the community. One way is to ensure the implementation of exchanges comfortable and effective, including through in the changing of tick size regulation

Changes latest tick size started from May 2, 2016. This decision contained in the Directors' Decree No. Kep-00023 IDX/BEI / 04-2016. The tick size is the bargaining limit of an effect determined by the Stock Exchange (Darmadji \& Fakhruddin, 2011). The attachment of the Decree contains that tick size is a unit of price change used in conducting a sell offer or a purchase request. The change in stock price is determined by the multiple of the fraction of the stock price. For example, for a fraction of the group share price IDR 2 then the price changes have multiples around IDR 2. For instance, of bargaining in shares at IDR 220, then the price of supply and demand that might is IDR 218 and IDR 222 or so. Any increase or decrease in the price multiples are called points. For example, shares at IDR 220 are experiencing increase 2 point, the price of the shares to IDR 224. The changing of tick size regulation in effect from May 2, 2016 (as in Table 1 ) is an important information for investors.

Changing of tick size regulation in the capital market have the main objective of increasing the liquidity of the Indonesian capital market. This is in line with the statement of the current Director of IDX, Tito Sulistio (2016) which states that tick size is a component of market micro structure which has an important role in increasing market liquidity and to improve market competitiveness.

This study using event study to examine the information content of the tick size changes in equity securities trading as the Decree of the Board of Directors of BEI number Kep-00023/BEI/042016. More specifically, the study aims to determine the effect of an information policy on the behavior of investors with a view abnormal returns occur around the time of the events and investor perceptions. The variables used were trading volume activity (TVA), abnormal return, and the perception of investors about liquidity.

Event study is the study of market reaction to an event that information is published as an announcement. Event study can be used to test the information content of an announcement and can also be used to test the semi strong form market efficiency (Jogiyanto, 2015).

Table 1. Changes in Tick Size May 2, 2016 Prevailed Tick Size

\begin{tabular}{|c|c|c|}
\hline \multicolumn{3}{|c|}{ Prevailed Tick Size } \\
\hline Stock Price Group & Tick Size & Maximum Change \\
\hline$<$ IDR 500 & IDR 1 & IDR 20 \\
\hline IDR 500 - < IDR 5,000 & IDR 5 & IDR 100 \\
\hline$\geq$ IDR 5,000 & IDR 25 & IDR 500 \\
\hline \multicolumn{3}{|c|}{ New Tick Size } \\
\hline \multicolumn{3}{|c|}{ Valid From 2nd May 2016} \\
\hline Stock Price Group & Tick Size & Maximum Change \\
\hline$<$ IDR 200 & IDR 1 & IDR 10 \\
\hline IDR $200-<$ IDR 500 & IDR 2 & IDR 20 \\
\hline IDR 500 - < IDR 2.000 & IDR 5 & IDR 50 \\
\hline IDR $2.000-<$ IDR 5.000 & IDR 10 & IDR 100 \\
\hline$\geq$ IDR 5.000 & IDR 25 & IDR 250 \\
\hline
\end{tabular}

Source: IDX 


\section{Jurnal Keuangan dan Perbankan | KEUANGAN}

Vol. 21, No. 3, Juli 2017: 366-375

If an announcement contains information, it is expected that the market will react when the announcement is received by the market. This market reaction is indicated by changes in the price of securities. Value price changes can then be calculated using returns or by using abnormal return or not return to normal.

According to Jogiyanto (2015), abnormal return or excess return is the excess of the actual return occurs to the normal return. Return to normal is the expected return made by investor. Thus, the abnormal return is the difference from the real return is reduced by the expected return. Return realization or real return is the return that occurs at a particular time that is the difference from the current price relative to the previous price. The expected return is the return expected by investors. In this study, testing the difference abnormal returns before and after the change will indicate a tick size in the market's ability to absorb information exchange. If an announcement contains information, it is expected that the market will react when the announcement is received by the market. This market reaction is indicated by changes in the price of securities. Value price changes can then be calculated using returns or by using abnormal return or not return to normal. Use of the abnormal return on event study of another used by Sublime (2010), Sayekti (2010), Alfiano \& Fauziah (2013), Natasya \& Suganda (2013).

Some researchers use the TVA in test of information content using the event study (Noble, 2010; Makaryanawati, 2012; Alfiano \& Fauziah, 2013; Natasya \& Suganda, 2013;). Husnan in Nugroho (2006) states that TVA is the ratio between the number of shares traded on a certain time to the number of shares outstanding at any given time. Whereas according to Wayss in Chandra (2015) the liquidity of an exchange can be described by measuring the liquidity of shares actively traded. Liquidity of a stock is measured by indicators such as the number of shares out- standing, trading frequency, trading volume, price change, and the spread. This research also uses TVA as one indicator of stock exchange liquidity. The higher the TVA of an exchange, the more liquid the exchange. TVA is a model used to determine changes in daily stock trading volume. In this study TVA is used to view the liquidity of the stock by testing the information content of the tick size changes.

\section{METHODS}

This study uses event study aimed to compare the liquidity conditions and content of information before and after the change in the tick size. Jogiyanto (2015) states that the event study a study of the market reaction to an event that the information is published as an announcement. This study is divided into two basic methods, namely calculation of TVA and abnormal return using secondary data derived from the Stock Exchange and the perception of investors using the instrument in the questionnaire form. The selected research window is 5 days before the change in the tick size and 5 days after the change considering that 5 days is the number of effective trading days in a week.

The population in this study are 536 public companies listed on the Stock Exchange in November 2016. The method of sample selection is purposive sampling method with the following criteria: (1). Companies listed on the IDX at the time of announcement of price fraction changes; (2). Manufacturing Companies consisting of three sectors namely industrial sector consumer goods, various industries, and basic industries and chemicals. Manufacturing companies are selected because companies in this sector are in great demand in stock trading on the stock; (3) The company listed do not perform corporate actions such as dividend, rights issue, stock split, merger, or acquisition during the period of observation; and (4) The 
company's stock traded each day in the period of observation with the observation window for 5 days before and 5 days after the change in the tick size.

The population of primary data are investors in Yogyakarta. Samples were selected using purposive sampling method provided that the respondent is an investor already invested in shares since before May 2, 2016.

Secondary data in this study were obtained from IDX and yahoofinance.com, namely: (1) Daily stock price for 12 trading days around the announcement of the change in stock price fraction divided within five days before the announcement and five days after the announcement; (2) Trading volume for 12 trading days around the announcement of changes in stock price fraction divided at five days prior to the announcement and five days after the announcement; (3) Number of shares outstanding from the sample companies (4) Composite Stock Price Index (CSPI) daily for 12 trading days around the announcement of changes in stock price fraction divided on five days before the announcement and five days after the announcement;

\section{TVA and Abnormal Return}

According to Beaver in Maulidiyah (2014), TVA obtained form:

TVA $i, t=\frac{\Sigma \text { Excanges } \mathrm{i} \text { which are traded on the day } \mathrm{t}}{\sum \text { Exchanges } \mathrm{i} \text { which are circulated on the day } \mathrm{t}}$

As Luhur (2010), Sayekti (2010), Alfiano \& Fauziah (2013), as well as Natasya \& Suganda (2013), This study also uses abnormal return calculated based on the following equation:

$\operatorname{RTN}_{i, t}=R_{i, t}-E\left[R_{i, t}\right]$
Where:

$\mathrm{RTN}_{\mathrm{i}, \mathrm{t}}=$ abnormal return security $\mathrm{i}$ in period $\mathrm{t}$ all events

$\mathrm{R}_{\mathrm{i}, \mathrm{t}} \quad=$ return the realization that occurs for the securities $i$ in the period of $t$ event

$E\left[R_{i, t}\right]=$ the expected returns of securities $i$ the event period to $t$

\section{Secondary Data Analysis Tool}

Data analysis method used is descriptive statistical analysis and inferential statistical tests to compare the TVA and abnormal condition returns before and after the change in the fraction of the price. Inferential statistics used to test research hypothesis using Wilcoxon signed rank test. Test Wilcoxon signed rank test was used for this test is basically the same as the test paired sample $t$ test, but with a looser requirement that can be done to the data type ordinal, interval, and ratio and does not require a specific distribution. The significance level in this study was 0.05 or 5 percent. Results of significance greater than 5 percent indicate no difference.

\section{Primary Data Analysis Tool}

The first step is the primary data testing the reliability and validity testing continued with normality test data using kolmogorof-Smirnov test to determine the shape of data distribution. If the data are normally distributed then further testing using different test paired sample t-test, but if the data were not normally distributed then the next $\mathrm{n}$ testing is using Wilcoxon signed rank test.

To obtain investor perception data on capital market liquidity, this research uses indicators based on Darmadji and Fakhrudin (2015), Satiari (2009) and Enrico (2013), as Table 2. 


\section{Jurnal Keuangan dan Perbankan | KEUANGAN}

Vol. 21, No. 3, Juli 2017: 366-375

Table 2. Indicators Survey Research Instruments (Indicators Exchange Liquid according Darmadji \& Fakhruddin (2015)

\begin{tabular}{ll}
\hline \multicolumn{1}{c}{ Liquidity Indicator } & \multicolumn{1}{c}{ Question } \\
\hline $\begin{array}{ll}\text { Transactions can be done } \\
\text { easily and quickly }\end{array}$ & - Stock transactions on the stock today are very easy. \\
& - Stock transactions on the stock today are very fast \\
& - There are no obstacles to making transactions in stock \\
The difference in demand and & - I do not need to raise or lower the price too far to buy or sell the stock I want. \\
bid prices is very slim & - In general, the difference between the supply and demand prices on the \\
& - stock is very thin \\
$\begin{array}{l}\text { The depth and breadth of the } \\
\text { market and the price movement is a } \\
\text { rapid reaction to information }\end{array}$ & - I use the information I get to transact on the exchange. \\
\hline & In other studies, often added indicators: \\
\hline $\begin{array}{l}\text { Trade Volume } \\
\text { in Satiari, 2009) }\end{array}$ & - I see the number of shares traded on high volume exchanges \\
The small transaction costs & The transaction fee is not a problem for me. \\
\hline
\end{tabular}

\section{RESULTS}

\section{TVA and Abnormal Return}

Based on the result of calculation of average abnormal return and TVA as table 3, seen fluctuating result on average abnormal return. At T-3 before the fractional change there was a decrease in abnormal return to show negative abnormal return, but in the study window after the change ie on $\mathrm{T}+2, \mathrm{~T}+3$, and $\mathrm{T}+4$ also showed negative value. This shows that it is precisely abnormal return has decreased after the changes in the fraction of the price. The average TVA tends to be more stable with smaller changes. The highest average TVA on T- 1 was $0.14 \%$ while the lowest TVA was on $\mathrm{T}+2$ at $0.07 \%$. The increase and decrease in average TVA tends not to be too large.
Table 3. Descriptive statistics Average 5 Day 5 Day Before and After Changes Tick size

\begin{tabular}{lcc}
\hline Day & $\begin{array}{c}\text { On average } \\
\text { Abnormal Return } \\
(\%)\end{array}$ & $\begin{array}{c}\text { Average TVA } \\
\mathbf{( \% )}\end{array}$ \\
\hline $\mathrm{T}-5$ & 0.61 & 0.09 \\
$\mathrm{~T}-4$ & 0.66 & 0.08 \\
$\mathrm{~T}-3$ & -0.17 & 0.09 \\
$\mathrm{~T}-2$ & 1.45 & 0.09 \\
$\mathrm{~T}-1$ & 1.34 & 0.14 \\
$\mathrm{~T}$ & 1.68 & 0.11 \\
$\mathrm{~T}+1$ & 0.04 & 0.11 \\
$\mathrm{~T}+2$ & -0.13 & 0.07 \\
$\mathrm{~T}+3$ & -0.22 & 0.08 \\
$\mathrm{~T}+4$ & -0.83 & 0.09 \\
$\mathrm{~T}+5$ & 0.39 & 0.10 \\
\hline
\end{tabular}


Figure 1 shows the movement of the average abnormal changes return and TVA:

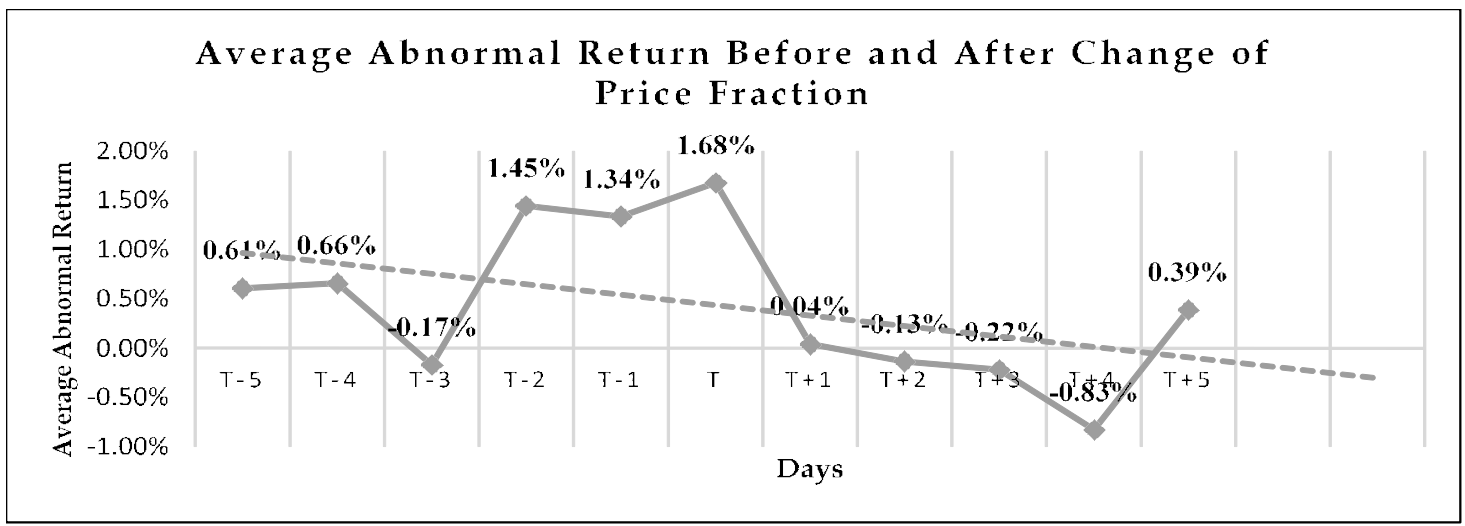

Figure 1. Graph average Abnormal Return Before and After Changes Tick size

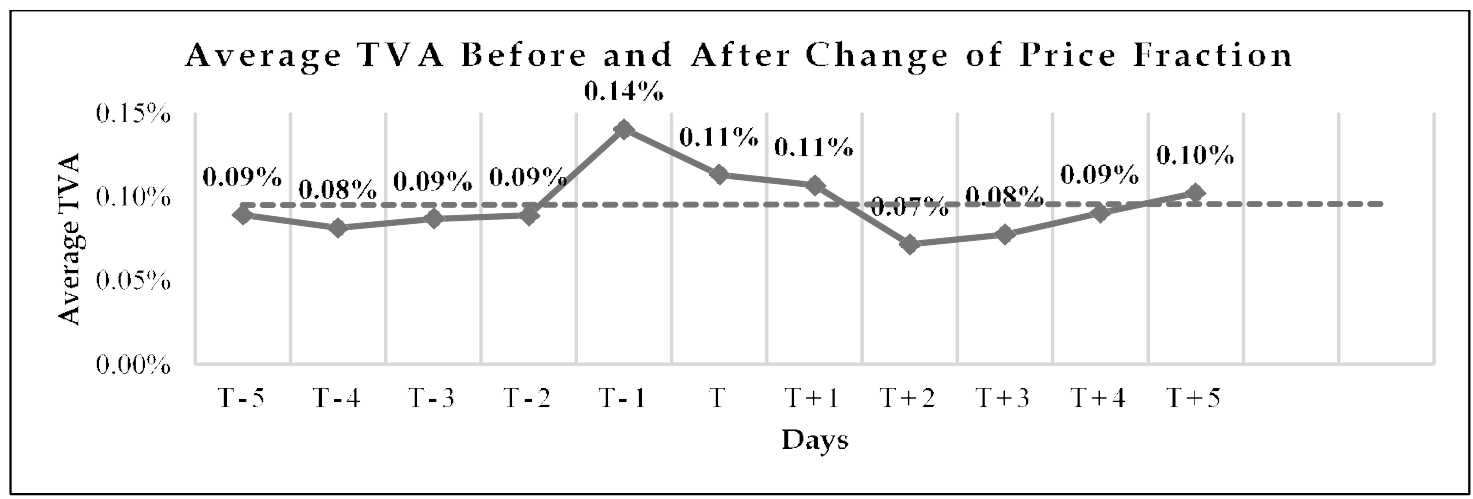

Figure 2. Graph average TVA Before and After Changes Tick size

Table 4. Results of the Wilcoxon Sign Rank Test Abnormal Return

\begin{tabular}{|c|c|c|c|c|}
\hline \multicolumn{5}{|c|}{ Ranks } \\
\hline & & $\mathbf{N}$ & $\begin{array}{l}\text { Mean } \\
\text { Rank }\end{array}$ & $\begin{array}{l}\text { Sum of } \\
\text { Ranks }\end{array}$ \\
\hline \multirow[t]{4}{*}{$\begin{array}{l}\text { AR_After - } \\
\text { AR_Before }\end{array}$} & $\begin{array}{l}\text { Negative } \\
\text { Ranks }\end{array}$ & $48^{\mathrm{a}}$ & 32.01 & $1,536.50$ \\
\hline & $\begin{array}{l}\text { Positive } \\
\text { Ranks }\end{array}$ & $16^{\mathrm{b}}$ & 33.97 & 543.50 \\
\hline & Ties & 1c & & \\
\hline & Total & 65 & & \\
\hline \multirow{3}{*}{\multicolumn{5}{|c|}{$\begin{array}{l}\text { a. AR_After }<\text { AR_Before } \\
\text { b. AR_After }>\text { AR_Before } \\
\text { c. AR_After }=\text { AR_Before }\end{array}$}} \\
\hline & & & & \\
\hline & & & & \\
\hline \multicolumn{5}{|c|}{ Test Statistics $^{a}$} \\
\hline \multicolumn{5}{|c|}{ AR_After - AR_Before } \\
\hline $\mathrm{Z}$ & & & & $-3.322^{b}$ \\
\hline $\begin{array}{l}\text { Asymp. Sig. } \\
\text { a. Wilcoxon } \\
\text { b. Based on }\end{array}$ & $\begin{array}{l}\text {-tailed) } \\
\text { gned Ranks } \\
\text { sitive ranks }\end{array}$ & & & .001 \\
\hline
\end{tabular}

After testing using descriptive statistics, subsequent hypothesis testing using Wilcoxon signed rank with the consideration that the data test results do not meet the normal distribution assumption.

The test results show that the significance of the Wilcoxon signed rank test 0.001 or $<0.05$, which means there is an average difference abnormal returns before the change in the fraction of the stock price and after change in the fraction of the stock price. Based on these results, it can be seen that most of the sample firms experienced a decline in average abnormal return after changes in the fraction of the price, the number of 48 companies from a total of 65 companies. 


\section{Jurnal Keuangan dan Perbankan | KEUANGAN}

Vol. 21, No. 3, Juli 2017: 366-375

Table 5. Wilcoxon Sign Rank of TVA

\begin{tabular}{|c|c|c|c|c|}
\hline \multicolumn{5}{|c|}{ Ranks } \\
\hline & & $\mathbf{N}$ & $\begin{array}{l}\text { Mean } \\
\text { Rank }\end{array}$ & $\begin{array}{c}\text { Sum of } \\
\text { Ranks }\end{array}$ \\
\hline \multirow{6}{*}{$\begin{array}{l}\text { TVA_After - } \\
\text { TVA_Before }\end{array}$} & Negative & $35^{\mathrm{a}}$ & 33.91 & $1,187,00$ \\
\hline & Ranks & & & \\
\hline & Positive & $29 \mathrm{~b}$ & 30.79 & 893.00 \\
\hline & Ranks & & & \\
\hline & Ties & $1 \mathrm{c}$ & & \\
\hline & Total & 65 & & \\
\hline \multirow{3}{*}{\multicolumn{5}{|c|}{$\begin{array}{l}\text { a. TVA_After }<\text { TVA_Before } \\
\text { b. TVA_After }>\text { TVA_Before } \\
\text { c. TVA_After }=\text { TVA_Before }\end{array}$}} \\
\hline & & & & \\
\hline & & & & \\
\hline \multicolumn{5}{|c|}{ Test Statistics ${ }^{a}$} \\
\hline \multicolumn{5}{|c|}{ TVA_After - TVA_Before } \\
\hline \multicolumn{4}{|l|}{$\mathrm{Z}$} & $-0.983^{b}$ \\
\hline \multirow{3}{*}{\multicolumn{3}{|c|}{$\begin{array}{l}\text { Asymp. Sig. (2-tailed) } \\
\text { a. Wilcoxon Signed Ranks Test } \\
\text { b. Based on positive ranks }\end{array}$}} & & 0.326 \\
\hline & & & & \\
\hline & & & & \\
\hline
\end{tabular}

The results showed that the Wilcoxon signed rank test of significance of 0.326 or $>0.05$, which means there is no difference in the average TVA before changes in stock prices and the fraction after the fractional change in stock prices. It can be seen that most of average TVA of the sample companies decreased after the price fraction change, ie 35 companies. While the average TVA of 29 other companies increased and the rest did not fluctuated.

\section{Description of Respondents}

Respondents obtained were 67 respondents. By gender, 26 respondents were female (38.8 percent) and 41 respondents were male (61.2 percent). Based on the job, 52 respondents were students (77.6 percent), 13 were employees of the private sector (19.4 percent), and 2 are self-employed (3 percent).

\section{Test the Validity and Reliability Questionnaire}

Test validity is used to indicate that the results of a valid study can be generalized. This study using Cronbach's alpha, to determine the level of how much items instruments representing the concept being measured. Reliability testing is used to ensure that the instrument is properly used to measure and accurate (Wiyono, 2011). This test uses the help of statistical applications. Validity and reliability tests are performed on each indicator. The testing results is as Table 6, which indicates that the 5 indicators are reliable and valid, so the results can be used for further processing.

Table 6. Validity and Reliability Test Results

\begin{tabular}{|c|c|c|c|}
\hline Indicator & $\begin{array}{c}\text { Cronbach's } \\
\text { Alpha }\end{array}$ & $\begin{array}{c}\text { The } \\
\text { correlation } \\
\left(\mathbf{r}^{2}\right)\end{array}$ & Information \\
\hline $\begin{array}{l}\text { Transactions can be done easily and } \\
\text { quickly }\end{array}$ & 0.813 & $>0.244$ & Reliable and valid \\
\hline $\begin{array}{l}\text { The difference in demand and bid prices } \\
\text { is very slim }\end{array}$ & 0.702 & $>0.244$ & Reliable and valid \\
\hline $\begin{array}{l}\text { The depth and breadth of the market } \\
\text { and the price movement is a rapid } \\
\text { reaction to information }\end{array}$ & 0.620 & $>0.244$ & Reliable and valid \\
\hline Trade Volume & 0.726 & $>0.244$ & Reliable and valid \\
\hline The small transaction costs & 0.750 & $>0.244$ & Reliable and valid \\
\hline
\end{tabular}




\section{Normality Test}

Normality test used to determine whether a population of normal distribution of data or not (Wiyono, 2011). Data that is normally distributed is a condition of using parametric statistical methods. This test can be done by testing one sample kolmogorof-Smirnov. Data is normally distributed if the significance value is greater than 0.05 .

Table 7. Results of Questionnaire Data Normality Test

\begin{tabular}{|c|c|c|c|}
\hline \multicolumn{4}{|c|}{ Tests of Normality } \\
\hline & \multicolumn{3}{|c|}{ Kolmogorov-Smirnova } \\
\hline & Statistic & Df & Sig. \\
\hline Total_Before & 0.089 & 67 & $0.200^{*}$ \\
\hline Total_After & 0.118 & 67 & 0.021 \\
\hline $\begin{array}{l}\text { *. This is a lor } \\
\text { a. Lilliefors } S\end{array}$ & $\begin{array}{l}\text { id of the } \\
\text { ce Corre }\end{array}$ & nifi & \\
\hline
\end{tabular}

Table 7 shows that respondents' data before the tick size changes are normally distributed with a significance value of 0.2 or $>0.05$, but the respondent's data after the change of tick size shows that the data is not normally distributed with a significance of 0.021 or $<0.05$. Due to the data were not normally distributed, then further testing use Wilcoxon signed ranks.

\section{Test Wilcoxon Signed Ranks}

The significance level in this study is 0.05 or 5 percent, so if the results of significance of more than 5 percent indicates no difference in the response of investors.

The result testing shows significant value to test Wilcoxon signed rank as how Table 8 amounted to 0.045 or $<0.05$. This indicates that there is difference of investor's response to market liquidity before and after change of stock price fraction. The majority of investors' response to capital market liquidity after the change of price faction was more positive or increased, that is 35 respondents assumed thus from total 67 respondents. A total of 15 investor responses to capital market liquidity after the change in tick size decreased and 17 others assumed that there was no difference.

\section{DISCUSSION}

This research was conducted to analyze the comparison of stock conditions before and after the latest price fraction policy changes that were implemented starting on May 2, 2016. The policy change fraction of the price for the stock will give

Table 8. Results of Wilcoxon Signed Ranks Test Data Questionnaire

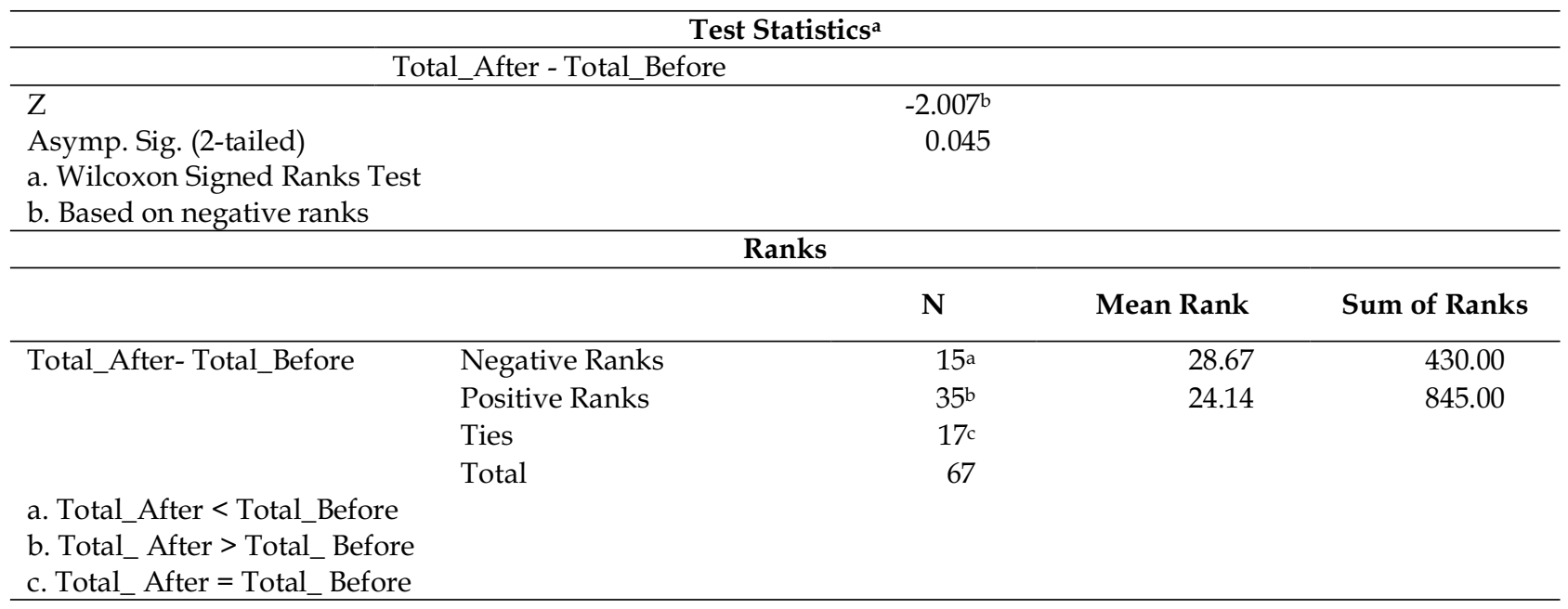




\section{Jurnal Keuangan dan Perbankan | KEUANGAN}

Vol. 21, No. 3, Juli 2017: 366-375

effect to the market. The objective of tick size change is to improve capital market liquidity. To determine the effectiveness of policy changes in the fraction of the price, in this study by comparing the TVA, abnormal returns, and investor response before and after the policy change in the fraction of the stock price.

The fractional change allows the investor to get a larger return for an increase in the price range as the fractions IDR 10 and to fractions IDR 2. These greater returns can be demonstrated in tests abnormal return. However, the abnormal test returns the two differ in the average abnormal returns before and after the change in the fraction of the price, but the changes tend to be negative or decreased (Table 4). The possible explaination is that the information on policy changes has been absorbed by the market so that investors do not get the increase in abnormal return.

TVA testing showed different results from testing abnormal returns. Investors also possible to get a larger return for an increase in the price range, should also be able to attract investors to increase their activities in the exchange, namely by doing more buying and selling of shares, thereby increasing the volume of trade. Nevertheless, the test results do not show significant TVA changes before and after the tick size changes (Table 5).

Investor perception research on liquidity before and after the latest tick size policy change is done to complement the result of secondary data analysis. Liquidity is measured based on several indicators, namely the speed and ease of transactions, the difference in demand and supply prices are thin, the depth and breadth of the market and price movement is a rapid reaction of information, as well as minimal transaction costs. The results showed that the majority of respondents (35 of 67) found a positive liquidity differences between before and after the policy change fraction latest price (Table 8 ). This shows that the policy changes the fraction of the price increase liquidity of capital markets, as the main purpose of the policy is issued by the Stock Exchange.

\section{CONCLUSIONS AND SUGGESTIONS}

\section{Conclusion}

This study aims to see changes in the stock before and after the stipulation of the fraction of stock price policy that started on May 6, 2016 ago. The change in stock tick size made by BEI aims to improve capital market liquidity and market competitiveness. This study variables using the average abnormal returns to determine the absorption of information by the market and the average TVA and the response of investors to see exchange liquidity before and after the change in the fraction of the price.

The test results of these variables showed differences in average abnormal returns before and after the change in the fraction of the price. Tests on TVA showed no difference before and after the change of stock price fraction, while the result of investor response test showed a positive difference of investor response regarding liquidity before and after tick size change. The existence of faction or group of such new shares IDR 2 fractions and fractions to IDR 10 that can provide a better return potential than the previous price faction system does not trigger a change or an increase in TVA. Tests on investor responses show positive outcomes, which means investors argue that stock liquidity after a policy change in the tick size is better. This is in line with the objective of the policy of tick size change, namely to increase market liquidity.

\section{Suggestions}

Liquid capital market is one of the main attraction for investors in investing so that BEI always make efforts to improve capital market li- 
quidity. The existence of faction or group of new shares as the fraction of IDR 2 and fraction of IDR 10 that can provide a better return potential than the previous price faction system. The results of the study, both based on primary and secondary data indicate that policy changes in the fraction of share prices on May 2, 2016 to increase liquidity. It can provide information to investors in investing, namely an increase in the liquidity of the stock and the potential for a better return with the change in the fraction of the price.

Nevertheless, the findings on secondary data showed the inconsistency. On average difference test abnormal returns before and after the change in the fraction of the price, shows the difference before and after the tick size changes. In testing TVA, showed no difference before and after change in the fraction of the stock price. The inconsistency of the results of this study provides an opportunity for subsequent research on the variables used in the study of events.

\section{REFERENCES}

Chandra, W. 2015. Pengaruh Perubahan Fraksi Harga dan Satuan Perdagangan terhadap Likuiditas Bursa Efek Indonesia. Jurnal Finesta, 3(1): 91-95.

Darmadji, T. \& Fakhruddin, H.M. 2011. Pasar Modal di Indonesia Pendekatan Tanya Jawab. Edisi Ketiga. Jakarta: Salemba Empat.

Jogiyanto, H. 2015. Teori Portofolio dan Analisis Investasi. Edisi Kesepuluh. Yogyakarta: BPFE.

Luhur, S. 2010. Reaksi Pasar Modal Indonesia Seputar Pemilihan Umum 8 Juli 2009 pada Saham LQ-45. Jurnal Keuangan dan Perbankan, 14(2): 249-262.

Makaryanawati. 2012. Reaksi investor atas Corporate Governance Perception Index (CGPI) 2011. Jurnal Keuangan dan Perbankan, 16(2): 196-204.
Maulidiyah, L. 2014. Analisis Pengaruh Stock Split terhadap AbnormalReturn dan Trading Volume Activity pada Perusahaan yang Terdaftar di BEI. Laporan Tugas Akhir. Manajemen Fakultas Bisnis dan Teknik Informatika Universitas Teknologi Yogyakarta.

Natasya, L.A. \& Suganda, T.R. 2013. Kandungan Informasi Pengumuman Saham Bonus: Studi Empiris di Bursa Efek Indonesia. Jurnal Keuangan dan Perbankan, 16(3): 389-399.

Nugroho, B.A. 2006. Pengaruh Perbedaan Hubungan Fraksi Harga Saham Baru terhadap Variabel Bid Ask Spread, Depth, dan Volume Perdagangan (Studi pada Fraksi Harga 5, 10, 25, dan 50 di Bursa Efek Jakarta). Tesis. Magister Manajemen Program Pasca Sarjana Universitas Diponegoro.

Nurfauziah, R.A. 2013. Analisis Dampak Penetapan UU No.28/2009 Terhadap AbnormalReturn dan Trading Volume Activity (Studi Kasus pada Perusahaan Rokok di BEI). Jurnal Optimum, 3(2): 107-200.

Peraturan Nomor II-A: Tentang Perdagangan Efek Bersifat Ekuitas.

Satiari, F. 2009. Analisis Perbedaan Sistem Fraksi Harga Saham terhadap Variabel Bid-Ask Spread, Depth dan Volume Perdagangan. Tesis. Magister Manajemen Program Pasca Sarjana Universitas Diponegoro.

Sayekti, F. 2010. Perbedaan Abnormal Return Saham Sebelum dan Sesudah Fatwa MUI Mengenai Haramnya Bunga Bank Konvensional: Event Study di Bursa Efek Indonesia. Jurnal Kompak, 17(2): 99213.

Undang-undang Nomor 8 Tahun 1995 TentangPasar Modal.

Wiyono, G. 2011. 3 in One: Merancang Penelitian Bisnis dengan Alat Analisis SPSS 17.0 \& SmartPLS 2.0. Yogyakarta: UPP STIM YKPN. 